\title{
Covid-19: UK budget gives $£ 94$ a week statutory sick pay to self-isolators and their carers
}

\author{
Elisabeth Mahase
}

The BMJ

As part of its 2020 budget the UK government will extend statutory sick pay of $£ 94.25$ ( $€ 108 ; \$ 121)$ a week to include people advised to self-isolate because of covid-19 and to those caring for them.

The medical evidence necessary to claim sick pay will also be relaxed in relation to covid-19, meaning that people will not require a GP's "fit" note. Instead, people will be able to get a notification from NHS 111 when they are advised to self-isolate, which they can use as evidence where necessary. "This notification would meet employers' need for evidence, whilst taking pressure away from general practices," the budget plan said. ${ }^{1}$

The budget was presented by the new chancellor of the exchequer, Rishi Sunak, who has been in post for less than a month, and set out how the government planned to tackle the impact of covid-19 on public services, individual people, and businesses. Included in the plan was $£ 5$ bn "to ensure [that] the NHS and other public services receive the funding they need to respond to the outbreak as the situation develops, and recover and return to normal afterwards."

\section{Underfunding and staffing}

The Nuffield Trust's chief economist, John Appleby, said that the extra funding was "good news" but that "staff and space are the resources that will really be needed, and the NHS starts in a deep hole after a decade of underfunding and understaffing." He added, "With tens of thousands of nursing posts already vacant and beds full to capacity, what can the service usefully spend this money on? The decision to keep the extra money in the Treasury for now may also mean NHS managers hold back, out of fear that they won't get what they spend refunded."
He said that the government's "failure to announce any real action to overhaul social care is the elephant in the room." He explained, "We are about to rely on these threadbare services to keep thousands of vulnerable patients out of hospital-and yet we still will not give them the funding and reform they have desperately needed for years. Coronavirus may serve as a reminder that inaction has consequences."

\section{Economically vulnerable people}

For people who cannot claim statutory sick pay, such as self-employed workers, the government has said it will provide support through the welfare system — but it did not provide further details on what this would mean in practice.

Meanwhile, local authorities in England will receive a portion of a new $£ 500$ m grant "to support economically vulnerable people and households in their local area" through council tax relief. The government said that it also planned to support businesses experiencing "increased costs or disruptions to their cash flow."

The budget document explained, "This includes expanded business rates reliefs, a coronavirus business interruption loan scheme to support up to a further $£ 1$ bn lending to small and medium sized enterprises, a $£ 2.2 \mathrm{bn}$ grant scheme for small businesses, and a dedicated helpline for those who need a deferral period on their tax liabilities."

1 Treasury HM, Sunak R. Budget 2020: documents. 11 Mar 2020. https://www.gov.uk/ government/publications/budget-2020-documents.

2 Treasury HM, Sunak R. HC 121-Budget 2020: delivering on our promises to the British people. 11 Mar 2020. https://assets.publishing.service.gov.uk/government/uploads/system/ uploads/attachment_data/file/871799/Budget_2020_Web_Accessible_Complete.pdf.

Published by the BMJ Publishing Group Limited. For permission to use (where not already granted under a licence) please go to http://group.bmj.com/group/rights-licensing/ permissions 